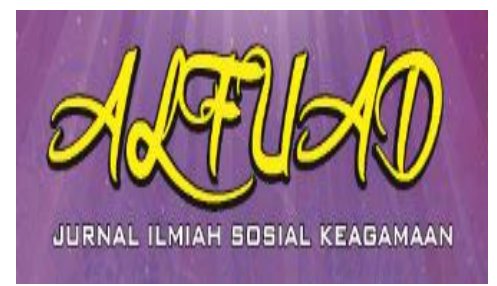

ALFUAD JOURNAL, 5 (2), 2021,(1-17)

(E-ISSN 2714-7606 P-ISSN 2614-4786 )

Available online at

http://ecampus.iainbatusangkar.ac.id/ojs/index.php/alfuad

\title{
Buddhism: An Overview of its Philosophy and Development in Russia
}

\section{Darni Yusna}

Universitas Islam Negeri Imam Bonjol Padang, Indonesia

E-mail: $\underline{\text { darniyusnafu@uinib.ac.id }}$

\begin{abstract}
It is a positivist philosophy that assumed a religious character, and it appeared in India after the Hindu Brahmin religion in the fifth century B.C. In the beginning, it was opposed to Hinduism and tended to take care of the human being. It also included a call to mysticism and harshness, and the rejection of luxury, and the call for love, tolerance, and doing good. After the death of its founder, it turned into false beliefs of a pagan nature, and its followers exaggerated its founder until he worshipped him. We conducted a literature study by reviewing various sources and using a descriptive analysis approach and a historical approach in presenting this article. It is considered an ethical system and a philosophical doctrine based on philosophical theories, and its teachings are not revelations but rather opinions and beliefs within a religious framework. Old Buddhism differs from New Buddhism in that the former is ethical, while New Buddhism is Buddha's teachings mixed with philosophical views and mental measurements about the universe and life. Buddhism has spread to all corners of the world, including Russia. Buddhism is considered one of the traditional religions in Russia, which is legally part of Russia's historical heritage. In addition to the historical monastic traditions of Buryatia, Kalmykia, and Tuva, Buddhism is now spreading throughout Russia, with some ethnic Russians converting to it. The main form of Buddhism in Russia is the Gelukpa school of Tibetan Buddhism, with other Tibetan traditions in the minority. Although Tibetan Buddhism is most often associated with Tibet, the religion spread to Mongolia, and via Mongolia, it was brought to Russia.
\end{abstract}

Keywords: Buddhism, Philosophy, Russia, Spread

\section{INTRODUCTION}

Buddhism in its infancy was against Brahmanic Hinduism, which was steeped in formalities and rituals. And Buddhism was destined to take care of a man. It was willing to bring him to the stage of Nirvana, which is the ultimate happiness, through rough living, selftorture, killing all its lusts, rejecting luxury, advocating love, tolerance, and doing good. After the death of its founder, it turned into a religion of a pagan character, based on the deification of Buddha, and it takes a social and religious nature that tends to atheism and varies in different places (De Bary, 1972).

Buddhism's evolution: (Siderits, 2017) 
Buddhists sanctified Buddha in great reverence and wrote a lot about his biography, works, and ideas. Various peoples and races entered into Buddhism, and as a result, Buddhism was divided into two parts. Ancient Buddhism: It is called southern; Because it is spread in Burma, Thailand, and Ceylon, and it is deifying and worshipping Buddha. Its leader is (Lama), based in Tibet, and his followers believe that God dwells in it and is characterized by intense monasticism. The new Buddhism: It is called the North. To spread in Japan, Korea, and China.

It is characterized by philosophy, depth, and the diversity of gods. In China, they believe that the gods are thirty-three, and the Japanese believe that their emperor is a descendant of the gods.

\section{A Brief History of the Spread of Buddhism}

The overall history of Buddhism states that this religion continued for twenty-five centuries. Buddhism developed during this long period, whether in terms of belief, application, literature, or associated institutions, such as temples and institutes. Buddhism invaded about thirty countries in Asia, and its influence was great. In the literature of these countries and their religious trends, and since the nineteenth century, Buddhist thought has contacted some countries of Europe, so
Buddhist thought has impacted Western philosophy, European literature, music, and other cultural art (Aich, 2013).

That is the whole statement about the expansion and spread of Buddhism, but giving details about this spread is almost impossible due to the lack of explicit material about it. In any case, it is possible to divide the age of Buddhism into five stages, each stage five centuries, to give the most prominent developments about Buddhism in each of these stages. The first period (from the beginning of Buddhism until the first century A.D.) witnessed a major transformation in the Buddhist belief concerning Buddha. Therefore, several conciliation conferences were held. But she could not persuade the masses to leave the place of God vacant as Buddha wanted it to be, so the dispute remained (Aich, 2013).

During this period, Emperor Asoka appeared, who pushed Buddhism outside the borders of India - as previously said and Buddhism began building temples, placing deities in them, establishing associations that sponsor social life, and supervising religious affairs, especially in India and Ceylon.

In the second period from the first century to the fifth century A.D. Buddhism began to spread towards the East to Bengal, the southeast to Cambodia and Vietnam, and the northwest to Kashmir. In 
the third century, it made its way towards the East to China and Central Asia, and its entry into China was by sea as well. From China, it headed to the north-east, entering Korea, and the activity of Chinese pilgrims who visited India, Ceylon, and Java between the years (399) and the year (414) A.D. The great spread of Buddhism in these areas and Buddhism in these areas cooperated fully with the monarchy, which was in control during these centuries over these countries. Through this link between religion and politics, Buddhism spread and many followers. This period witnessed clear progress in the Buddhist culture that established institutes and applied its heritage to its followers. Several relevant kinds of literature assisted the writing of this article. Among them, the literature is Early Buddhist Art of China and Central Asia by Marylin Martin Rhie. the spread of Buddhism including art and culture. This literature discusses in the following period from the sixth to the tenth century A.D. Buddhism continued to progress and spread, especially from Korea and China to Japan, India to Nepal, and then Tibet (Borup, 2013). During this period, pilgrims' activity increased, and their movement to the countries that Buddhism entered and did not. It was always strong. The spread of Buddhism or its decline depended on the strength and weakness of the connection. This period is considered one of the most colorful periods of Buddhism in cultural terms. The influence of Buddhism on literature and arts in all the countries it entered was clear. Writing is also assisted with literature entitled The Buddhist tradition in India, China \& Japan, written by William Theodor (De Bary, 1972). This book discusses the period of weakness in the spread and existence of Buddhism. In the following period - that is: from the eleventh to the fifteenth century Buddhism weakened, and many of its traces disappeared due to the return of Hindu activity in India, and the emergence of Islam in India, and in other countries where Buddhism was dominant, but Buddhism tended to be active in these The period - fleeing Islam - towards Laos, Mongolia, and Burma, and Buddhist cultural activity had a great impact during this period in Burma, Cambodia, Ceylon, and Japan (Martin Rhie, 2010, p. 76). As for the last period - from the sixteenth century to the tenth century - it is considered a delicate period in the history of Buddhism, as Buddhism stood face to face in the front of a challenge to Western thought that colonialism carried to those places. Western colonialism introduced its intellectual trends, educational reforms, and philosophies in various affairs, and Buddhism did not find it necessary for its different sects to cooperate to stand in the face of intellectual advance, and thus the 
Buddhist groups met or brought each other close to each other; To strengthen the struggle in its battle with Western Christianity and European philosophies, Buddhism has adopted many Western trends, and Christianity has imbibed some Buddhist ideas. Publications were exchanged between the supervisors of these two philosophies and the development of education in temples. Buddhists and Westerners. The author also conducted a Journal of Historiepolitique, entitled Tibetian Studies in Russia: a Brief Historical Accounts by Alexander Zorin. This article discusses the history of Buddhism in Russia from the Middle Ages and its status during the Tsarist and Communist periods. At the end of this period, Buddhism collided with communism, and the rule in many of the countries in which Buddhism spread was in the hands of communist governments.

\section{METHOD}

In writing this article, a literature study and a descriptive analysis approach have been carried out on the sources that have been studied comparatively. Starting from data collection, verifying the data obtained, and then analyzing the data and comparing them, the final stage concludes the results of the study, which is expected to give a new nuance to Buddhism and spreading in various parts of the world, especially in Russia.

\section{RESULT AND DISCUSSION}

Founded by Siddhartha Gautama, nicknamed Buddha (560 - 480) B.C., Buddha means the world, and he is also called Skimuni, which implies retreat. Buddha grew up in a town on the borders of Nepal, and he was a prince; he grew up in luxury in bliss, he married at the age of nineteen, and when he reached twenty-six, he abandoned his wife, turning to asceticism, austerity, roughness in living, contemplation of the universe and selfdiscipline. He resolved to work on the salvation of man. From his pain stemming from desires, he called to adopt his point of view, as many people followed him. The followers of Buddha gathered after his death at a great conference in the village of Rajagraha in the year (483 BC). A.D. to remove the dispute between the followers of the doctrine and to codify the teachings of Buddha; For fear of losing their assets, they entrusted this to three monks: (Siderits, 2017). (1) Kashyapa was concerned with mental issues. (2) Oyali was involved with the rules of selfpurification. (3) Ananda has written down all the sayings and dialogues. For the fourth requirement: the founder of Buddhism. The founder of Buddhism is a 
man called: Buddha, and his name is Siddhartha or Siddhartha.

The Buddha, to whom this religion is attributed, is the son of a ruler. He was born in the Lumbini Garden near the city of Kapila Vastu in northern India, in the region of Nepal, in the year (568) B.C. His dates of birth vary, but what was mentioned is the most likely saying on the date of his birth. And the legends talk about his birth and before, and the days of his pregnancy, so remember that he was born to clean, not as children are born, but came down from his mother's womb while she was standing holding a branch. She did not feel pain, and his body was clean as a mirror, and they mentioned miracles and dignity to him. As for his name, he was called Siddhartha, or Siddhartha - as it has been passed - and it's meaning: the one who fulfilled his hope. As for his titles, they are many. Among them are (Shakyamuni), the wise man of the Shakyas tribe, and (Biskyamuni), meaning: the one in retreat. Among his titles is Tathagata, which means: the man who wins the truth. As for Buddha, it means the enlightened or the knowledgeable (De Bary, 1972). Buddha grew up in his country on the border of Nepal and was a prince; He grew up in luxury, learned horsemanship, and his historians exaggerated every little thing in his life until they claimed that four thousand dancers were dedicated to making his heart happy and that his wife was selected from five hundred beautiful women (Pelevin \& Bromfield, 2000). He married at the age of sixteen - and it was said: at the age of nineteen - his wife, Yaswada bint, one of the leaders of the Koli tribe, and he lived with her happily and contentedly, and she bore him his son Rahula. After ten years of his marriage, he resolved to search for the truth no matter what it cost him after he had experienced many kinds of pain because of the sorrows and misfortunes he saw. He resolved to work to rid man of his pain that stemmed from desires and then called for adopting his point of view as many people followed him. One night he decided to leave the palace, deserted his wife and son, went down to the stable, and chose his white horse and his servant (Shana). They claim that one of his miracles, while he was preparing to leave the palace, was that its doors opened on their own, and the sound of his horse's footsteps was not heard. Even if he ended up in the Anima River, he got off his horse and took off the jewels that he was adorned with, cut his sword, and gave it all to his servant, and ordered him to go back to his father's palace, and tell him his story (Snelling, 1993). 


\section{A liquid passed by and exchanged clothes with him.}

Then, after seven days, he moved from Anima Beach and left for the city of Ajajriha, the capital of King Bambia of the Kingdom of Magadha, where he resides in the caves of the Wandia Hills, hermits who stopped their lives for contemplation and reflection and to study the philosophies of ancient India; Please come together to solve the problem of life, and unravel its closed mysteries, and he went to the cave in which the people of Alarakalama and Adaka, and the fame of Alara Barhami was wide. And when he entered the cave of Alara, he found him immersed in his contemplation and thought, so he stood in reverence and silenced in his hands, and he thought: - Do you see that he has the key to the secret? After that, he sat down with them, took from them what they had, studied the books of the Vedas and the Upanishads, and made a cave for him, which was admired by all the hermits, and he had a good life of asceticism and austerity.

After two years, he realized that Brahmanism is incapable of solving the riddle of existence and the problem of life; he went to a forest in Bengal, became hard on himself, and underwent the most severe forms of austerity and deprivation, and spent six years in this condition until he was on the verge of destruction, and his reputation spread in the horizons. But that torture of the body and complete stillness did not lead him to his goal. Rather, the weakness that he suffered as a result of torture hindered him from strength and thinking. Then he resolved after that to leave the life he had led, which led his five hermit followers to dissuade him from his determination, but they did not succeed. They considered it apostasy, accused him of deviating from the road, and left him and went to the meadow of Al-Ghazal in the city of Benares. Siddhartha - the Buddha - regained his vigor and strength and went to a tree, and sat under it, and saw a man with weeds; So he asked him for a fist, and he gave it to him, and he sat cross-legged with his hands and feet and resolved not to leave his place, and not to send what he contained until the light of wisdom and knowledge descends on him. He made it necessary for himself to remain even if his bones had rotted, his skin dried up, and his body was damaged (Emmanuel, 2017). And the legends say: The impulses of himself began to wrestle with him, but he triumphed over the temptation and defeated it in the struggle, and the night was almost over, and the earth was covered with the age of dawn until the sublime truth, and true knowledge shone with him in his heart and mind, and he realized what he had hoped for from the past, present and future, all indivisible. 
And he knew the secret of life and death, the cause and effect, and the journey of the soul in various bodies: when it ascends to Nirvana where the general nothingness, and the annihilation of the soul, which is the tranquillity and devastation. But it is annihilation that is not the known destruction; rather, it is an existence that perishes like the destruction of the colors of the spectrum in the sun, in its pure, colorless whiteness, as some modern Buddhist philosophers claim. Nirvana is not reached until after the purity of the soul and the virtues in the world of sense and reality. The day and then the night passed by him, and he did not perceive them; Because he was immersed in his praises, then the victor's awakening awoke with joy in his heart; Because he achieved what he had hoped for, and what he had hoped for was completed, and enlightenment descended on him, so he was Buddha (Rusli, n.d., p. 66).

His fame increased, and the people went to him, and he went to Banaras. He went to Marj al-Ghazal to the five hermits who mocked him, accused him, and left him, so they hardly saw him until his prestige defeated them and took care of his appearance; they rose to greet him, raced to greet him, and brought water to wash his feet, so he gave them the first lesson of his lessons, and joy-filled their hearts, and overflowed their faces with people. After that, his fame resounded in the horizons of India. His new law attracted the youth of ancient families, and the crowds turned to him and many of his followers. And he became a caller for what he reached until he died at the age of eighty in the year (488) B.C., and his body was burned eight days after his death. This is how legends say about him (Almond, 2006).

\section{Buddhist Figures}

Founded by Siddhartha Gautama, nicknamed Buddha (560 - 480) B.C., Buddha means the world, and he is also called Skimuni, which implies retreat. Buddha grew up in a town on the borders of Nepal, and he was a prince; he grew up in luxury in bliss, he married at the age of nineteen, and when he reached twenty-six, he abandoned his wife, turning to asceticism, austerity, roughness in living, contemplation of the universe and selfdiscipline. He resolved to work on the salvation of man. From his pain stemming from desires, he called to adopt his point of view, as many people followed him (Snelling, 1993). The followers of Buddha gathered after his death at a great conference in the village of Rajagraha in the year (483 BC). A.D. to remove the dispute between the followers of the doctrine and to codify the teachings of Buddha; For fear of losing their assets, they entrusted this to three monks:(Aich, 
2013). (1) Kashyapa was concerned with mental issues. (2) Oyali was involved with the rules of self-purification. (3) Ananda has written down all the sayings and dialogues.

\section{Buddhist beliefs, ideas, and teachings}

Buddhist beliefs, ideas, and teachings include many myths, many falsehoods, and various contradictions, including:(Aich, 2013). (1) Atheism: At the beginning of his call, Buddha did not talk about divinity and avoided delving into matters of the unseen. (2) Buddhists believe that Buddha is the Son of God, the Savior of humanity from its tragedies and pains and that He bears their sins for them. (3) They say: The birth of Buddha was indicated by a star that appeared on the horizon of the sky, and they call it (the Buddha's principal). (4) They say: When Buddha was born, the soldiers of heaven rejoiced, and the angels sang songs of love for the blessed newborn. (5) They say about the Penal Code and denying the Resurrection and the Last Day; They see that man must be punished for his deeds, good and evil, but they see that happening in the life of this world, so they deny the resurrection, and they deny heaven and hell. (6) They believe that Buddha's appearance has changed in his last days; Where a light descended on him that surrounded his head, and a great light shone from his body; Those who saw him said: What is this human being? $\mathrm{He}$ is nothing but a great God. (7) Buddhists pray to Buddha, and they believe that he will enter them into Paradise, and prayers are performed with them in meetings attended by many of his followers. (8) When Buddha died, his followers said: $\mathrm{He}$ ascended to heaven with his body after completing his mission on earth. (9) They say transmigration of souls: This is the result of their disbelief in the Last Day; This led them to claim transmigration; They believe that whoever dies has his soul moved to a new neighborhood; If the second passes, it moves to the third, and so on to infinity; Then they claim - based on the law of retribution - that the soul receives its reward of bliss or misery as it moves from body to body. This belief is secret to many religions and sects that say reincarnation. (10) They believe in the return of the Buddha to the earth; To restore peace and blessing to her. (11) In the Buddha's teachings, the call to love, tolerance, good treatment, giving alms to the poor, abandoning wealth and luxury, and compelling oneself to be austere and harsh. It contains a warning against women, money, and a temptation to stay away from marriage. (12) Buddha believes that the basis of religiosity is meditation and resistance to tendencies, and he put four basic facts in his claim, which 
are:(Sablin, 2018) (a) Life is suffering. (b) Desires are the root of this trouble. (c) The suffering stops when the cravings stop. (d) Abolishing desires and is accomplished by following what he called the noble path. This path is based on the availability of health and correctness in belief, determination, speech, behaviour, and the profession taken to earn a living, effort, and intellectual and spiritual contemplation. With this spiritual, intellectual, and behavioural self, he reaches Nirvana, the ultimate happiness, and then desires and emotions are abolished, and the reincarnation of souls stops. A happy Buddhist survives the cycle of birth and death; It reaches Nirvana where there is neither birth nor death, and this stage is the lack of reincarnation, which is one of the naughty necessities of the soul. It is said that Buddha reached this during six years of endurance and exercise of the soul and that he spent the remaining forty-five years of his life teaching what he had finished with his experience. Nirvana then - attains it by the Buddhist after he breaks all the chains and shackles that bind himself and prevent it from realizing the facts, and turns away from the desire for survival, and is possessed by a calm and reassured mind that does not infiltrate error, and is free from all wishes, desires, ignorance, and the causes of deception and temptation. After all this, the Buddhist attains the stage of Nirvana. It has been said that Nirvana is a union with God, but Buddhism does not know a god. (13) Beggary and unemployment: One of the teachings of Buddhism is that it advises its followers to give up their money, real estate, and trades, and recommends that they extend a hand to others by begging and begging; They live on unemployment and laziness.

Unlike Islam, these are teachings with which life is not upright, and nations do not rise with them. It is a religion that commands work, activity, and strength and forbids laziness and unemployment. This is a brief about the beliefs of Buddhism, and it is noted that there is a great similarity between them and Christianity, which confirms that Christianity has been affected by it in many beliefs.

\section{Buddha in Russia}

In Russia, the main form of Buddhism is the Gelukpa school of Tibetan Buddhism, known informally as the "Yellow Hat" tradition, with other Tibetan and non-Tibetan schools as minorities. Although Tibetan Buddhism is often associated with Tibet, it spread into Mongolia and through Mongolia into Siberia before spreading to Russia. 
Datsan Gonzishwini in Saint Petersburg is the northernmost Buddhist temple in Russia.

The first evidence of the presence of Buddhism in the territory of modern Russia (more specifically Siberia, the nearest region of East Asia) dates back to the 8th century A.D. It is associated with the state of Balhae, which occupied part of today's Primorye. And things. The Mohi, a people whose culture was greatly influenced by neighbouring China, Korea, and Manchuria, practised Mahayana Buddhism. It initially spread in those regions of Russia geographically or culturally adjacent to Mongolia (the area known as the Mongolian steppes) or inhabited by Mongolian ethnic groups: Buryatia, Krai across the Baikal, Tuva, and Kalmykia. The last of this region was the only Buddhist region in Europe, located in the North Caucasus. By 1887, there were 29 publishing houses and many dastans. In 1917 among these ethnic areas were approximately 20,000 Buddhists and 175 temples. When the Soviet Union came into being, all religions, including Buddhism, began to be viewed as "tools of oppression," and Buddhists in positions of power were considered unfavourably. By 1917, Joseph Stalin made sure that there was no open datsan in the country. The USSR sought to eliminate Buddhism and other religions, as they believed that the lack of faith combined with urbanization would lead to increased production (Snelling, 1993). In 1929 many monasteries were closed, and monks were arrested and exiled. By the 1930s, Buddhists were suffering more than any other religious community in the Soviet Union. The lamas were expelled and accused of being "Japanese spies" and "enemies of the people." In 1943, all Kalmyk residents were forcibly exiled to Siberia due to government suspicions that they collaborated with Nazi Germany when it occupied part of Kalmykia. About $40 \%$ of the Kalmyk population died while in exile, and the survivors could not return to their homeland until 1956.

However, Buddhism did not disappear from Russia due to Pedia Dandaron, a follower of Tseddinov, a scholar of Buddhism, and a famous thinker. Dandarun attempted to revive Buddhism in the state of atheism by introducing the concept of neo-Buddhism, a mixture of Buddhist teachings and contemporary Western philosophy with scientific theories. Dendron was later arrested for forming a religious community and eventually died in a concentration camp. However, his disciples played a major role in the 1990s with the revival of Russian Buddhism. (Zorin, 2020) Historically, Buddhism was incorporated into Siberia in the early 17 th century. 
Buddhism is one of the traditional religions of Russia and is legally part of the Russian historical heritage. Besides the historical monastic traditions of Buryatia, Tuva, and Kalmykia, the latter has a Buddhist majority republic only in Europe. Buddhism is now spread throughout Russia, with many converts of Russian descent (Vasil Timerjanovich Sakaev, E.T. Al., 2020).

Buddhists have lived in Russia for about four centuries after coming from Mongolia. Today, they are looking to restore their heritage, build temples, and transform their regions into leading cultural and religious tourism destinations. Buddhists have always lived in Russia, who came from Mongolia about 400 years ago, freely and enjoyed a high degree Of independence in the tsarist era. However, they were persecuted under the Soviet leader, Joseph Stalin. In the absence of accurate statistics, the editor-in-chief of the magazine "Buddhism in Russia" Andrei Terentyev estimates that the number of Buddhists there is more than half a million people, concentrated in the republics of Kalmykia, Buryatia, and Tuva, all professing Tibetan Buddhism, in addition to adherents of Buddhism in Moscow, St. Petersburg, and other major cities. Terentyev told Al-Araby Al-Jadeed: "The Buddhists began to appear in Russia about 400 years ago when the Oirat tribes migrated from the Asian region of Dzungaria, so they continued to travel for a few decades until they reached the banks of the Volga River. The region protected the Russian borders, and the Oirat was allowed to maintain their independence and their Buddhist religion, so they settled lands in the vicinity of the city of Astrakhan and the Caspian Sea region, which is today called the Republic of Kalmykia. On how Buddhism expanded during the reign of Tsarist Russia, he added: "After the passage of fifty and one hundred years, the majority of the Buryats converted to Buddhism, and it became a dominant religion in Eastern Buryatia. The Republic of Tuva, which was part of the Chinese Empire, was under the Buddhist leadership in Mongolia; then, It became a Russian protectorate after gaining independence from the Qing Dynasty in 1914 (Martin Rhie, 2010). These three regions are still the main centres of Buddhism in Russia today. Since the end of the nineteenth century, the Russians themselves began to show an increasing interest in the East in general and Buddhism in particular. The refusal of the Orthodox Church did not prevent the opening of a Buddhist temple in the Russian capital at the time, Petrograd, in 1915, amid the rise in the number of Buddhists in it to about 200 individuals, among whom were Russians. After 
establishing the Soviet Union and Stalin's rise to power, Buddhists, like adherents of all religions, lived through difficult years with the closure and looting of monasteries and the arrest of many lama priests in the 1930s. But after the end of World War II (1939-1945), Stalin moved towards a more tolerant policy with religions, allowing Buddhism in Buryatia alone. This situation continued until the era of reforms (Perestroika) during the last leader of the Soviet Union, Mikhail Gorbachev, in the eighties of the previous century. Terentyev comments on the status of Buddhism in the Soviet era and after, saying: "Buddhism and other religions were subjected to persecution in the age of the Soviet Union, but two monasteries were opened after World War II, and the number of monasteries began to increase steadily after the dissolution of the Soviet Union and reached about 100 by today Compared to about 150 monasteries in 1917. Also, Buddhism began to spread among the Russian people, bringing the number of new converts to Buddhism, including about 15 to 20 thousand. About 30 years ago, construction work was underway in Moscow, which has not yet been completed (Snelling, 1993, p. 91).

Terentyev points out that Buddhists in Russia today no longer practice their religion freely but are also working to transform Buddhist monuments into tourist destinations, pointing to the success of the experience of the Republic of Kalmykia in attracting tourists due to the easy access to its capital, Elista, located in the south of the European part of Russia. Recreational excursions to the Republic of Buriatia, situated in Southeast Siberia. On the other hand, there are obstacles to organizing tourist trips to the neighbouring Republic of Tuva due to the difficulty of accessing it, according to the Russian researcher.

With the prolonged restrictions on travel abroad due to the Corona pandemic, Russian tourism companies are betting on marketing various types of trips within Russia. The search on the sites of Russian tourism companies shows that it is possible to book an expedition to southern Russia, for example, that includes visiting some Buddhist cities and monuments in Elista at prices starting at about $\$ 300$ per person, including accommodation and shrines, provided that the tour travels to the destination with his knowledge and at his expense.(Snelling, 1993)

It is noteworthy that Buddhism is the fourth most prevalent religion in the world after Christianity, Islam, and Hinduism, and the number of its adherents is about half a billion people, or about 7 per cent of the world's total population, according to figures on the website of the American Pew Center for Studies (Sablin, 2018). 


\section{CONCLUSION}

Russia is a huge country! The Christian religion prevails on its territory (Orthodox). However, this is not the only religion that has been officially confirmed in Russia. One of the widespread religions is also Buddhism. In some regions of the country, this religion is less common, but there are also regions such as Buddhism as the main religion. In terms of the global spread of Buddhism, it also occupies one of the top places (III-IV) in the main list of beliefs. On the territory of the Russian Federation, Buddhism began to develop for a long time. This eastern religion of a Russian person is not friendly and new. But it is worth noting that its popularity is growing over time. And if you may say so, the Buddhist fashions in Russia are already firmly established. And not without reason. Buddhism is interesting, multifaceted, colourful. It would be curious even to those who profess other religious teachings or adhere to critical opinions about that religion. Especially widely, Buddhism is common in Biyatia, Kalmykia, and the Republic of Taiva.

The people living in these subjects of the Russian Federation preach this religion. There are Buddhist temples in the republics. For example, the main Buddhist temple, located in Elista, is a place of pilgrimage, to which people come from all over Russia and from other countries.
There are many sacred Datsunovs in Poeta. In the Republic of Taiva, there are existing Buddhist monasteries. But this debt is distributed not only in these regions only. Temples - Buddhists in Moscow, Saint Petersburg, in Sverdlovsk, Irkutsk Region. Of course, the peoples of Russia, such as the Buryats, Kalmyks, Tuvuntsy, are mostly Buddhist. However, the traditional carriers of this religious culture in Russia are not only followers of this religion. Today you can make more and more people confess Buddhism in the central sector of the country, the southern region, Central Russia. These are mainly representatives of the youth class. If you believe the historical references, Buddhism originated in Russia in the distant seventh century. The first mentions of this religion on Russian soil are found in historical testimonies about the state of Bohai. It was located in this state on the lands, and today it is called Amurur or Primorye. It is believed that most of the Buhaoji people recognized complaining. However, the Bohahai knew Mahiya (one of the main Buddhist teachings). For example, the Heiti poet Buhai often dedicated his lines to the theme of six births (dharma). If the archaeological excavations on the lands where the Bohai people lived earlier, Buddhism was one of the major religions recognized these lands. Many Buddhas, Bodhisattvas, and other items directly 
related to this culture were discovered when the holes were found.

Kalamaki made a significant contribution to the development of Buddhism on the Russian land. The Kalmyks are believed to be followers of Buddhism with a holistic and historically assured view. For them, this religion is not new, normal, nor relevant. Wellestablished Buddhism was firmly entrenched in the lands of Kalmykia long before the accession of the republic to Russia. Read the story about Uygur Buddhism. Buryatia is also a great ancestor of this culture on the Russian land. In distant times, hundreds of artists from Mongolia and Tibet for long time lived in Boratia. They brought their teachings there, which were firmly secured on these lands. For a long time, this religion was recognized by the Altai peoples.

But it should be noted that shamanism and Christianity made their mark on Altai Buddhism. In 1964, Buddhist teaching was recognized in Russia. During this period, the position of the Pandeto Hambo Lama was officially introduced, which was aimed at domination in the Trans-Siberian and Eastern regions. Since then, the religion has been formally recognized in the country. Buddhism recognized a fairly high percentage of the population of modern Russia.Distribution of Buddhism in Russia in our time. It was founded in the 19th century and developed by the Buddhist community in Saint Petersburg. The northern capital became the centre of Russian Buddhism. But the XIX-XX century - this is the period when religion developed and flourished.

On the contrary, the development of this region calmed down due to the influence of the political sphere. By the end of the XX century, Buddhism was taken in Russia with a new force and developed dynamically. Today, this religion is fully present in our country and is becoming more and more followers. Young people are actively interested in Buddhist teaching. Many adherents of this teaching and representatives of the average age group (30-40 years). Someone comes to this religion consciously in adulthood, and someone is a fundamental religion that was initially accepted into the family. Buddhism in Russia: basics and features. The basis of this religion is the unique teaching of Buddha, who, like many other saints, is considered a man already living on earth. The exercise is based on four noble truths. Following the teachings, a person should be healed of spiritual pain and live happily and dignifiedly in this world. There are many schools of Buddhism that exist. Depending on which school the person professing this faith is in, his views of peace and life prevail. 
However, the difference in principles and knowledge is small. In the centre of this religion always lies the good, love, and the way to get rid of suffering. Features of Buddhist views change depending on where Buddhism is spread in Russia. For example, it could be a conservative school of Theravada and perhaps a Mahyana faith. Mahinda school in Russia was represented by two main currents: Zen and Sleep. Followers of Zen Buddhism study the depth of human consciousness. They want to know the nature of the mind.

Adherents of sleep practitioners in teaching, hypnotic practices, monasticism, asceticism. Most of the representatives of this religion in our country recognize the operations of the Jaluja School. Also, a lot in the Russian Federation Foundation of the Karma Kaji School. In the central part of Russia, the Mahayana doctrine is widespread. Zen followers on the territory of the country are much less. ZenBuddhism is represented in the Russian lands by the Korean school of Kwan of Mind. On the territory of Altai, Kalmykia, Tibetan Buddhism is widely distributed. Many adherents of the Tibetan school are in Moscow, St. Petersburg, the southern part of the Russian Federation (Rostov-ondon, Krasnodar Territory).

\section{Russian Buddhists}

It is believed that more than $1 \%$ of the population was professing this religion. Among the Atbars, there are the so-called ethnic Buddhists. These are people born in the republics, wherein Russian Buddhism has a long-standing historical root and is the main religion. Also, in our country, many young Buddhists came to this faith due to the study and adoption of oriental culture. If there were hundreds a hundred years ago, Russian Buddhists seemed to be Karnak orthodox people who were really in wonder in the southern and central regions of the country; today, this religion does not surprise anyone.

On the contrary, in our time, a variety of once destroyed Buddhist temples have been restored. In addition to Elista, Buryatia, Tuva, Buddhist assurance can be found in the Sverdlovsk region; in St. Petersburg, there are several temples at once, there is a charter in Irkutsk. There are Buddhist communities in different cities of our country, where people who know the religion find media and spiritual support. Today you can find special literature in any library. The network is also shot from various thematic materials. Receiving saturation of information in this direction is easy without the help of some organizations and societies. The basis of this religion is man's love for the whole life and the world as a whole. You can 
come to this love and harmony through self-knowledge and meditation. Four basic truths, the accelerated Buddha, say: "Everyone is under the influence of suffering. This suffering is always a cause. You can get rid of any suffering from any suffering. Remission from suffering - is an authentic path to Nirvana."

Buddhism is based on a clearly defined framework. The Buddha said that each person should find the "golden mean" between complete asceticism and abundance. The lifestyle of a happy person is based on the awareness of important principles in WorldView that help obtain nobility, kindness, and love. It is important to understand that Buddhism is not a religion of "Jalak"; in its centre is God, thanks to which worship can be achieved. Buddhism is, first of all, philosophy, where you can know yourself, the universe and take the highest truth to improve your stay on this earth. The main objectives of the practice are not achieved through punishment or fear.

On the contrary, Buddhism relies on only love and kindness. It is believed that it is possible to approach higher realities by getting rid of suffering. And you can only get rid of suffering from nature. In Buddhist teaching, there is an eight path to salvation. These are eight points, observe what you can find knowledge and become on the road to liberation. Proper understanding: the world consists of suffering and grief.

Faithful intentions: It is important to realize your way and know how to curb passion. Correct speech: The word must bear deep and good meaning. Thoughtful Actions: All things should be gentle, not empty and satisfying. Great Efforts: All activities should aim for the good. Phil's thoughts: Only get rid of bad reviews; you can avoid and suffer about suffering.

Concentration: only the ability to focus on an important one; and get rid of secondary assistance to be worthy of passing the path of bilateral salvation. A proper lifestyle: Only a person will achieve a decent life to get rid of the charge of suffering and pain. Sincerely observing these simple rules, a person follows a charitable path of purification. All this happens consciously and thus gives the expected results. However, to pass such a method, a person must be aware of the many things that exist in this world, making several amazing discoveries in himself and others and changing their understanding and world. Buddhists in Russia and other countries around the world are native. Typically, followers of this teaching are intellectually developed and have expectations of scale, peace, and modesty. 


\section{REFERENCES}

Aich, T. (2013). Buddha philosophy and western psychology. Indian Journal of Psychiatry, 55(6), 165. https://doi.org/10.4103/00195545.105517

Almond, P. C. (2006). The British discovery of Buddhism (Digitally printed first paperback version). Cambridge Univ. Press.

Borup, J. (2013). Buddhism in the West. In A. L. C. Runehov \& L. Oviedo (Eds.), Encyclopedia of Sciences and Religions (pp. 290-297). Springer Netherlands. https://doi.org/10.1007/978-14020-8265-8_157

De Bary, W. T. (Ed.). (1972). The Buddhist tradition in India, China \& Japan. Vintage Books.

Emmanuel, S. M. (Ed.). (2017). Buddhist Philosophy: A Comparative Approach. John Wiley \& Sons, Inc. https://doi.org/10.1002/978111942 4246

Martin Rhie, M. (2010). Early Buddhist Art of China and Central Asia, Volume 3: The Western Ch'in in Kansu in the Sixteen Kingdoms Period and Inter-relationships with the Buddhist Art of Gandh?ra. BRILL. https://public.ebookcentral.proquest .com/choice/publicfullrecord .aspx? $\mathrm{p}=1079749$

Pelevin, V., \& Bromfield, A. (2000). Buddha's little finger. Viking.

Rusli, A. R. (n.d.). KARMA DAN ETOS KERJA DALAM AJARAN BUDHA. 13.

Sablin, I. (2018). Official Buddhism in Russia's Politics and EducationReligion, Indigeneity, and
Patriotism in Buryatia. Entangled

Religions, 5, 210-249.

https://doi.org/10.46586/er.v5.2018 .210-249

Siderits, M. (2017). Personal Identity and Buddhist Philosophy: Empty

Persons (1st ed.). Routledge. https://doi.org/10.4324/978131524 7052

Snelling, J. (1993). Buddhism in Russia:

The story of Agvan Dorzhiev,

Lhasa's emissary to the tzar.

Element.

VASIL TIMERJANOVICH SAKAEV, ET AL. (2020). Political Aspects of Demographic Processes in Muslim Community in Russia. https://d oi.org/10.5281/ZENODO.4 280080

Zorin, A. V. (2020). Tibetan studies in Russia: A historical sketch. International Institute for Buddhist Studies of the International College for Postgraduate Buddhist Studies. 